\title{
Korelasi Antara Konsep Diri dengan Kemampuan Pemecahan Masalah IPS
}

\author{
Ni Made Ayu Wardani ${ }^{1}$, Ni Wayan Suniasih ${ }^{2}$, Wayan Sujana ${ }^{3}$ \\ 1,2,3 Jurusan Pendidikan Guru Sekolah Dasar, FIP \\ Universitas Pendidikan Ganesha \\ e-mail: deayu2196@gmail.com ${ }^{1}$, niwayan.suniasih@undiksha.ac.id², \\ iwayan.sujana@undiksha.ac.id ${ }^{3}$
}

\begin{abstract}
Abstrak
Penelitian ini bertujuan untuk mengetahui korelasi antara konsep diri dengan kemampuan pemecahan masalah IPS siswa kelas V SD Gugus Untung Surapati, Kecamatan Denpasar Timur, pada Tahun Pelajaran 2017/2018. Jenis penelitian ini adalah penelitian ex post facto, korelasional. Populasi dari penelitian ini adalah siswa kelas $\mathrm{V}$ yang berada di Gugus Untung Surapati, Denpasar Timur Tahun Pelajaran 2017/2018 yang berjumlah 525 orang siswa. Penentuan sampel menggunakan teknik proportional random sampling dengan taraf kesalahan 5\% sehingga diperoleh banyak sampel dari populasi adalah 213 siswa. Data diperoleh melalui hasil angket konsep diri dan tes esai kemampuan pemecahan masalah IPS yang dikerjakan oleh responden. Teknik analisis data pada penelitian ini menggunakan analisis korelasi product moment. Sebagai uji prasyarat analisis adalah uji normalitas sebaran data. Berdasarkan hasil analisis diperoleh $r_{\text {hitung }}=0,446$. Pada taraf signifikansi $5 \%$ dengan $n=213$, maka diperoleh $r_{\text {tabel }}=0,138$. Karena $r_{\text {hitung }}=0,446>r_{\text {tabel }}=0,138$ maka dapat diartikan bahwa $\mathrm{H}_{0}$ ditolak dan $\mathrm{H}_{\mathrm{a}}$ diterima. Jadi, dapat disimpulkan bahwa terdapat korelasi yang signifikan antara konsep diri dengan kemampuan pemecahan masalah IPS Kelas V SD Gugus Untung Surapati, dengan arah korelasi positif, artinya semakin tinggi konsep diri yang dimiliki siswa maka semakin meningkat pula kemampuan pemecahan masalah IPS siswa. Berdasarkan hasil penelitian tersebut, konsep diri memiliki hubungan dalam kemampuan pemecahan masalah siswa khususnya dalam muatan pembelajaran IPS, sehingga dukungan dari berbagai pihak sangat diperlukan agar konsep diri positif siswa dapat terbentuk dengan baik dan kemampuan pemecahan masalah siswa dapat berkembang secara optimal.
\end{abstract}

Kata Kunci : konsep diri, kemampuan pemecahan masalah

\begin{abstract}
This study aims to determine the correlation between self-concept with the ability to solve the problem of Social Science students of grade V elementary school Gugus Untung Surapati, East Denpasar District, academic year 2017/2018. This type of research is ex post facto, correlational research. The population of this study is a class V student in Gugus Untung Surapati, East Denpasar academic year 2017/2018 which amounted to 525 students. Determination of the sample using proportional random sampling technique with $5 \%$ error rate that obtained many samples from the population is 213 students. The data obtained through self-concept questionnaire and essay test of Social Science problem solving ability done by the respondents. Data analysis technique using product moment correlation analysis. As a prerequisite test is the normality test of data distribution. Based on the analysis result obtained $r_{\text {count }}=0,446$. At the significance level of $5 \%$ with $n=213$, then obtained $r_{\text {table }}=0,138$. Because $r_{\text {count }}=0.446>r_{\text {table }}=0.138$ it can be interpreted that $H_{0}$ rejected and $H_{a}$ accepted. So it can be concluded that there is a significant correlation between self-concept with the ability to solve the problem of Social Science Class V SD Gugus Untung Surapati, with a positive correlation direction, meaning that the higher self-concept owned by students will further improve students problem solving skills of Social Science. Based on the results of the research, self concept has correlation with problem solving ability of students especially in social science, support from various parties is needed to formed positive self-concept and the problem solving ability of students can develop optimally.
\end{abstract}

Keywords: self concept, problem solving ability of Social Science. 


\section{Pendahuluan}

Pendidikan merupakan suatu proses yang diperlukan untuk mendapatkan keseimbangan dan kesempurnaan dalam perkembangan individu maupun masyarakat. Penekanan pendidikan dibanding dengan pengajaran terletak pada pembentukan kesadaran dan kepribadian individu atau masyarakat di samping transfer ilmu dan keahlian. Dengan proses semacam ini suatu bangsa atau negara dapat mewariskan nilai-nilai keagamaan, kebudayaan, pemikiran dan keahlian kepada generasi berikutnya, sehingga mereka betul-betul siap menyongsong masa depan kehidupan bangsa dan negara yang lebih cerah (Nurkholis ,2013).

Pasal 1 UU SISDIKNAS no. 20 tahun 2003 disebutkan bahwa Sistem Pendidikan Nasional adalah keseluruhan komponen pendidikan yang saling terkait secara terpadu untuk mencapai tujuan pendidikan nasional. Berangkat dari bunyi pasal ini dapat diketahui bahwa pendidikan adalah sistem yang merupakan suatu totalitas struktur yang terdiri dari komponen yang saling terkait dan secara bersama menuju kepada tercapainya tujuan (Soetarno, 2003: 2). Adapun komponen-komponen dalam pendidikan nasional antara lain adalah lingkungan, sarana-prasarana, sumberdaya, dan masyarakat. Komponen-komponen tersebut bekerja secara bersama-sama, saling terkait dan mendukung dalam mencapai tujuan pendidikan (Munirah, 2015).

Martoella (1987) mengatakan bahwa pembelajaran Pendidikan IPS lebih menekankan pada aspek "pendidikan" dari pada "transfer konsep", karena dalam pembelajaran pendidikan IPS peserta didik diharapkan memperoleh pemahaman terhadap sejumlah konsep dan mengembangkan serta melatih sikap, nilai, moral, dan keterampilannya berdasarkan konsep yang telah dimilikinya. Dengan demikian, pembelajaran pendidikan IPS harus diformulasikannya pada aspek kependidikannya (Purnomo, 2016).

Pendidikan IPS dapat memberikan kontribusi yang cukup besar dalam mengatasi masalah sosial, sebab pendidikan IPS memiliki fungsi dan peran dalam meningkatkan sumber daya manusia untuk memperoleh bekal pengetahuan tentang harkat dan martabat manusia sebagai mahluk sosial, keterampilan menerapkan pengetahuan tersebut dan mampu bersikap berdasarkan nilai dan norma sehingga mampu hidup bermasyarakat. Kedudukan konsep ilmu, teknologi dan kemasyarakatan semakin penting dalam era masyarakat modern yang banyak menimbulkan masalah-masalah kompleks. Kenyataan ini akan semakin dirasakan apabila dalam penjelasanya memberi informasi lebih jauh bahwa pemecahan masalah-masalah tersebut menghendaki adanya kedudukan dari berbagai disiplin ilmu (Tri, 2017).

Setiap manusia dalam menjalankan kehidupannya tidak pernah terlepas dari kegiatan pembelajaran, baik pembelajaran di lingkungan formal seperti sekolah maupun non-formal yaitu di lingkungan masyarakat. Walaupun kedua lingkungan tersebut memberikan pembelajaran yang berbeda, namun terdapat sebuah persamaan, yaitu sama-sama mendapatkan pengalaman yang dapat dijadikan pembelajaran untuk membentuk kemampuan kognitif berdasarkan masalah-masalah yang ditemukan selama pembelajarannya, atau secara sederhana individu tersebut memperoleh kemampuan kognitif berdasarkan pengalamannya dalam memecahkan masalah pada kehidupan sehari-hari individu tersebut.

Setelah beranjak ke usia 7-12 tahun yang dikenal dengan masa operasional konkret seperti yang dikemukakan oleh Piaget (Boeree, 2013:277) "di tahap ini (operasional konkret), seorang anak tidak hanya menggunakan simbol-simbol dalam kerangka representasi, tapi juga mampu memanipulasi berdasarkan logika, namun mereka tetap harus menjalankan prinsipprinsip tersebut dalam konteks situasi konkret (nyata)". Pada usia tersebut, individu itu telah memasuki jenjang pendidikan formal yaitu Sekolah Dasar (SD) saat memasuki jenjang pendidikan formal, individu tersebut memiliki nama akademik yaitu siswa. Siswa tidak hanya mendapatkan pengalaman belajar dari sumber belajar pada buku maupun media atau alat peraga. Mereka juga mendapatkan pembelajaran dari teman sepermainan mereka atau dikenal dengan nama tutor sebaya. Dari hal itu, siswa akan dievaluasi dan mendapatkan nilai dari hasil kegiatan pembelajarannya. Belajar menurut Slameto (2010) dipengaruhi oleh, 1) faktor internal yang meliputi: faktor jasmaniah, faktor psikologis, dan faktor kelelahan, serta 2) faktor eksternal yang meliputi keluarga, sekolah dan masyarakat.

Berdasarkan pemaparan Slameto, ada salah satu faktor internal yang mampu mempengaruhi kegiatan belajar siswa bahkan dapat mempengaruhi hasil belajar siswa yaitu konsep diri. Konsep diri adalah seluruh elemen yang membuat seseorang memiliki pandangan tentang dirinya. Orang tua memiliki peran yang sangat penting dalam pembentukan konsep diri. "Konsep diri terbentuk dan berkembang secara gradual dalam proses pengasuhan termasuk interaksi interpersonal antara ibu-anak" (Bachri, 2013:123). 
Konsep diri merupakan salah satu bagian penting dalam membentuk 'diri' seseorang. "Konsep diri (self-concept) adalah penilaian terhadap karakter, kekuatan dan kelemahan diri" (Latipah, 2012:243). Sejalan dengan pemikiran Latipah, Bachri (2013:122) mengemukakan bahwa "konsep diri merupakan gambaran diri, penilaian diri, dan penerimaan diri yang bersifat dinamis, terbentuk melalui persepsi dan interpretasi terhadap diri sendiri dan lingkungan, mencakup konsep diri umum (general self-concept) dan konsep diri yang lebih spesifik (specific self-concept) termasuk konsep diri akademis, sosial, dan fisik". Penilaian-penilaian ini berasal dari pengalaman dan pengamatan yang seorang anak pelajari dari lingkungannya. Berdasarkan pengertian ahli tersebut, secara keseluruhan konsep diri adalah gambaran, pandangan dan penilaian mengenai diri sendiri yang terbentuk dari persepsi dan interpretasi terhadap diri sendiri dan lingkungan.

Dari paparan dan pengertiannya, konsep diri secara tidak langsung memberikan pengaruh untuk menentukan tingkat hasil belajar atau tentang cara siswa untuk menyelesaikan atau memecahkan masalah yang terkait dengan pembentukan pengetahuan siswa secara mandiri (kontruksitivistik).

Masyarakat khususnya orang tua dan guru belum banyak mengenal kajian teori dan pemahaman tentang konsep diri pada anak-anak atau siswa. Terkadang dalam menentukan faktor keberhasilan seorang siswa dalam hal pembelajarannya, konsep diri seringkali tidak masuk dalam bahan pertimbangan mereka. Padahal konsep diri menurut William D Brooks (Sutoyo, 2012:308) ada dua yaitu, 1) Konsep diri positif yang beberapa cirinya adalah dapat menerima dirinya apa adanya dengan segala kekuatan dan kelemahannya, seseorang mampu bertindak berdasarkan penilaian tanpa merasa bersalah, dan seseorang mempunyai kemampuan untuk menyelesaikan persoalan. Sedangkan, 2) konsep diri negatif yang beberapa cirinya adalah seseorang bersikap pesimis, enggan bersaing dengan orang lain, dan merasa tidak berdaya.

Selama proses membentuk konsep diri, siswa akan menghadapi berbagai macam masalah dalam hidupnya. Dalam memecahkan masalah tersebut, siswa harus memiliki kemampuan untuk menemukan sebuah solusi. Solusi tersebut didapat dari pengalaman dan pengamatan yang telah dilakukan siswa semasa hidupnya. Dari kemampuan siswa memecahkan masalah tersebut, akan membantu siswa dalam membentuk konsep dirinya. Semakin baik kemampuan siswa dalam memecahkan masalahnya, maka akan terbentuk konsep diri positif. Kenyataannya kebanyakan siswa, cenderung mengeluh dan menyerah dalam mencari solusi untuk memecahkan masalahnya, sehingga secara tidak langsung membentuk konsep diri yang negatif pada siswa tersebut.

Disisi lain, orang tua cenderung menilai keberhasilan anak-anaknya dari hasil belajar yang diperoleh, namun orang tua tidak menyimak proses pembelajaran anaknya di sekolah. Terkait dengan hasil belajar siswa, yang cukup penting adalah tentang siswa tersebut membentuk pengetahuannya sendiri berdasarkan pengalaman belajar yang diperolehnya dan masalah-masalah yang berhasil diselesaikannya. "Idealnya aktivitas pembelajaran tidak hanya difokuskan pada upaya mendapatkan pengetahuan sebanyak-banyaknya, melainkan juga menggunakan segenap pengetahuan yang didapat untuk menghadapi situasi baru atau memecahkan masalah-masalah khusus yang ada kaitannya dengan bidang studi yang dipelajari" (Wena, 2012:52). Dalam hal ini, pemecahan masalah dipandang sebagai suatu proses untuk menemukan kombinasi dari sejumlah aturan yang dapat diterapkan dalam upaya mengatasi situasi yang baru tersebut. "Pemecahan masalah (problem solving) merupakan sebagai proses menerapkan pengetahuan (knowledge) yang telah diperoleh siswa sebelumnya ke dalam situasi yang baru" (Susanto, 2014:195).

Dari pemaparan tersebut, siswa tidak hanya diukur kemampuannya untuk mendapatkan hasil belajar yang baik, namun orang tua siswa juga sebaiknya mengetahui tingkat kemampuan pemecahan masalah yang dimiliki siswa. Hal inilah yang menjadi acuan orang tua untuk mengetahui tentang tingkat kemampuan pemecahan masalah siswa pada tiap-tiap muatan pembelajaran pada tema di kelasnya masing-masing.

Salah satu muatan pembelajaran yang ada pada kurikulum 2013 di tingkat Sekolah Dasar adalah muatan pembelajaran IPS. IPS merupakan ilmu yang mempelajari gejala-gejala alam dan tingkah laku manusia. Susanto (2014:145) menyatakan,

tujuan utama dari pembelajaran IPS adalah untuk mengembangkan potensi peserta didik agar peka terhadap masalah sosial yang terjadi di masyarakat, memiliki sikap mental positif terhadap perbaikan segala ketimpangan yang terjadi, dan terampil mengatasi setiap masalah yang terjadi sehari-hari baik yang menimpa dirinya sendiri maupun yang menimpa masyarakat. 
Mengacu pada latar belakang tersebut, maka akan dikaji tentang korelasi konsep diri siswa ini dalam sebuah penelitian dengan judul "Korelasi Antara Konsep Diri dengan Kemampuan Pemecahan Masalah IPS Siswa Kelas V SD Gugus Untung Surapati Kecamatan Denpasar Timur Tahun Pelajaran 2017/2018".

Kemampuan pemecahan masalah merupakan kecakapan seseorang dalam upaya mengatasi persoalan yang sedang dihadapi menggunakan seperangkat aturan atau prosedur, metode atau strategi, berdasarkan pengetahuan dan keterampilan yang didapat dari pengalaman dan pengamatan yang dialami sebelumnya untuk menemukan sesuatu yang baru. 4 tahap utama dalam pemecahan masalah pada penelitian ini, antara lain: Identifikasi masalah, perencanaan penyelesaian, pelaksanaan rencana, dan generalisasi.

IPS adalah ilmu yang mengkaji seperangkat peristiwa, fakta, konsep, dan generalisasi yang berkaitan dengan isu sosial yang bahannya diambil dari berbagai ilmu sosial, seperti: geografi, sejarah, ekonomi, antropologi, sosiologi, politik, dan psikologi dan dikemas secara ilmiah untuk memberikan wawasan dan pemahaman yang mendalam kepada peserta didik, khususnya di tingkat dasar dan menengah.

Kemampuan pemecahan masalah sangat penting bagi siswa dan masa depannya. Hal ini dikarenakan kemampuan pemecahan masalah dalam batas-batas tertentu, dapat terbentuk melalui bidang studi dan disiplin ilmu yang diajarkan.

Konsep diri merupakan pandangan atau penilaian yang seseorang ketahui dan rasakan tentang perilakunya, isi pikiran dan perasaannya, yang terbentuk baik melalui pengalaman maupun pengamatan terhadap diri sendiri mencakup konsep diri jasmaniah, sosial, dan spiritual. Terdapat 2 jenis konsep diri, yaitu konsep diri positif dengan karakteristik dapat menerima dirinya apa adanya, mampu menerima kritik dan mampu mengatasi masalah yang sedang dihadapinya, dan konsep diri negatif dengan karakteristik pesimis, merasa tidak berdaya, peka terhadap kritik dan pujian serta mudah menyerah. Adapun faktor-faktor yang mempengaruhi konsep diri, yaitu pola asuh orang tua, significant other, self-perception, serta kekerasan dan depresi.

Konsep diri merupakan pandangan atau penilaian yang seseorang ketahui dan rasakan tentang perilakunya, isi pikiran dan perasaannya, yang terbentuk baik melalui pengalaman maupun pengamatan terhadap diri sendiri serta bagaimana perilakunya tersebut berpengaruh terhadap orang lain. Jika seorang siswa memiliki konsep diri yang positif, maka siswa tersebut dipastikan mampu memecahkan masalah yang dihadapinya. Hal ini sejalan dengan pendapat Taylor (dalam Bachri, 2013) yang menyatakan bahwa siswa yang mempunyai konsep diri positif secara nyata mampu mengatasi masalah dalam kehidupan keseharian, cenderung lebih independen, percaya diri dan bebas dari karakteristik yang tidak diinginkan seperti kecemasan, kegelisahan, perasaan takut yang berlebihan, dan perasaan kesepian.

Jadi, dengan terbentuknya konsep diri yang positif, maka akan berdampak positif pula kepada pembentukan karakter siswa, karena siswa mampu memecahkan masalah yang dihadapinya, terutama dibidang IPS, karena konsep diri terbentuk dari proses sosialisasi yang terjadi di lingkungan siswa sehari-hari.

\section{Metode}

Menurut Kerlinger (dalam Emzir 2012:119) "Penelitian ex post facto adalah penyelidikan empiris sistematis dimana peneliti tidak mengendalikan variabel bebas secara langsung karena perwujudan variabel tersebut telah terjadi, atau karena variabel tersebut pada dasarnya memang tidak diberikan perlakuan". Terkait dengan desain penelitian tersebut, Penelitian ini termasuk jenis penelitian ex post facto dengan studi korelasional karena dalam penelitian ini hanya mengungkapkan gejala yang terjadi seperti apa adanya serta mengungkapkan faktorfaktor yang berpengaruh dari variabel bebas terhadap variabel terikat. Dalam penelitian ini dibahas mengenai korelasi antara konsep diri dengan kemampuan pemecahan masalah IPS.

Terdapat dua variabel yang diteliti yaitu, pertama adalah variabel bebas yaitu variabel konsep diri $(X)$, sedangkan yang kedua adalah variabel terikat, yaitu variabel kemampuan pemecahan masalah IPS (Y). Apabila digambarkan arah korelasi dari kedua variabel tersebut, maka konstalasi variabelnya dapat digambarkan sebagai berikut. 


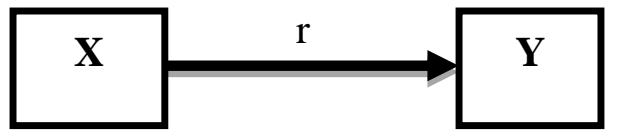

Gambar 1. Konstalasi variabel penelitian (Sugiyono, 2017:8)

Penelitian ini dilakukan pada April 2018. Lokasi penelitian yaitu SD di Gugus Untung Surapati Kecamatan Denpasar Timur Tahun Pelajaran 2017/2018. Populasi dalam penelitian ini adalah siswa kelas V SD Gugus Untung Surapati Kecamatan Denpasar Timur dengan jumlah populasi siswa kelas V SD Tahun Pelajaran 2017/2018 sebanyak 525 Siswa.

Penentuan sampel sangat membantu penelitian, terutama pada penelitian yang memiliki jumlah populasi yang banyak. "Sebagian kecil individu yang dijadikan wakil dalam penelitian disebut sampel" (Winarsunu, 2009:11). Sedangkan menurut Siregar (2013:30), "sampel adalah suatu prosedur pengambilan data di mana hanya sebagian populasi saja yang diambil dan dipergunakan untuk menentukan sifat serta ciri yang dikehendaki dari suatu populasi”. Jadi, dapat disimpulkan bahwa sampel adalah sebagian kecil dari populasi yang dipilih dan dapat mewakili karakteristik dari populasi (refresentatif) yang akan digunakan dalam penelitian.

Penentuan ukuran sampel menggunakan tabel dari Isaac and Michael (Sugiyono, 2017:71). Sesuai dengan tabel tersebut, jumlah populasi di Gugus Untung Surapati sebanyak 525 orang, sedangkan jumlah populasi yang mendekati dalam tabel Isaac and Michael yang mendekati jumlah populasi pada Gugus Untung Surapati adalah 550 orang, jadi jumlah sampel yang diambil dengan tingkat kesalahan $5 \%$ adalah 213 orang.

Setelah menentukan ukuran sampel, penentuan anggota sampel dalam penelitian ini menggunakan teknik proposional random sampling. Menurut Winarsunu (2009:12) "teknik sampling proposional digunakan apabila karakteristik populasi terdiri dari kategori, kelompok, atau golongan yang setara atau sejajar yang diduga kuat memiliki pengaruh pada hasil penelitian" dan "Sampling random merupakan cara pengambilan sampel dengan memberikan kesempatan yang sama pada anggota populasi untuk diambil menjadi anggota sampel" (Agung, 2014:71). Dengan demikian, dalam penelitian ini setiap siswa mendapatkan kesempatan yang sama untuk dijadikan sampel.

Dalam penelitian ini metode pengumpulan data yang digunakan yaitu metode tes dan non-tes. Teknik pengumpulan data dengan metode tes digunakan untuk memperoleh data mengenai kemampuan pemecahan masalah IPS. Instrumen yang digunakan untuk mengetahui kemampuan pemecahan masalah IPS pada siswa adalah tes esai. Indikator tes esai kemampuan pemecahan masalah meliputi, identifikasi masalah, perencanaan penyelesaian, pelaksanaan rencana, dan generalisasi. Cara pemberian skor pada tes esai ini menggunakan rubrik penilaian untuk menentukan nilai yang diperoleh oleh siswa. Penilaian pada instrumen ini berdasarkan rubrik penilaian dan dihitung menggunakan rumus.

$$
\text { Nilai }=\frac{\text { Shor mentah }}{\text { skor maksimal ideal }} \times 100
$$

(sumber: Sudijono, 2011:318)

Setelah instrumen kemampuan pemecahan masalah IPS dibuat dilanjutkan dengan pengujian validasi teoritik. Hal ini dilakukan agar tes esai kemampuan pemecahan masalah IPS dapat dikatakan layak untuk digunakan. Instrumen penelitian ini dinilai oleh dosen dan guru yang ada di sekolah.

Uji coba dilakukan untuk mendapatkan gambaran secara empirik angket yang telah disusun layak untuk digunakan sebagai instrumen penelitian.

Tabel 1. Kisi-Kisi Instrumen Tes Esai Kemampuan Pemecahan Masalah IPS

\begin{tabular}{clcc}
\hline \multirow{2}{*}{ Variabel } & \multicolumn{1}{c}{ Indikator } & Jumlah Item & No. Item \\
\cline { 2 - 4 } Kemampuan & Mengidentifikasi masalah & 3 & $1,2,3$ \\
Pemecahan & Perencanaan pemecahan masalah & 3 & $1,2,3$ \\
Masalah & Pelaksanaan pemecahan masalah & 3 & $1,2,3$ \\
& Generalisasi & 3 & $1,2,3$ \\
\hline
\end{tabular}


Sedangkan untuk pengumpulan data mengenai konsep diri digunakan jenis metode nontes berupa kuesioner atau angket. Kuesioner ini mengacu pada model skala Likert yang dimodifikasi dengan empat alternatif jawaban yang teknik penskorannya menggunakan politomi.

Instrumen konsep diri di adaptasi dari Mia (dalam Sutoyo, 2012: 310) dan di modifikasi sesuai dengan tata bahasa bahasa anak usia sekolah dasar.. Indikator mengenai konsep diri dalam penelitian ini meliputi, pemeliharaan dan pandangan terhadap kesehatan fisik, keinginan terhadap pemilikan suatu benda, penilaian terhadap hasil pekerjaan sekolah, kepuasan terhadap status intelektual yang dimiliki, keinginan mengembangkan bakat dan penyaluran minat/hobi, tingkat hubungan dengan anggota keluarga, pola pergaulan di lingkungan sekolah, dan keinginan beribadah dan melakukan kegiatan keagamaan. Setelah instrumen angket konsep diri dibuat dilanjutkan dengan pengujian validasi teoritik dan validitas empiris. Uji coba dilakukan untuk mendapatkan gambaran secara empirik angket yang telah disusun layak untuk digunakan sebagai instrumen penelitian.

Tabel 2. Kisi-Kisi Kuesioner Konsep Diri

\begin{tabular}{clcc}
\hline \multirow{2}{*}{ Variabel } & \multicolumn{1}{c}{ Indikator } & \multicolumn{2}{c}{ Sebaran Item/nomor } \\
\cline { 3 - 4 } $\begin{array}{c}\text { Konsep } \\
\text { Diri }\end{array}$ & Pesitif & Negatif \\
\cline { 2 - 4 } & Keinginaraan dan pandangan terhadap kesehatan fisik & $3,5,13$ & 14,18 \\
\cline { 2 - 4 } & Penilaian terhadap pemilikan suatu benda & 4,6 & 15,20 \\
\cline { 2 - 4 } & Kepuasan terhadap status intelektual yang dimiliki & 7,22 & 21,30 \\
\cline { 2 - 4 } & $\begin{array}{l}\text { Keinginan mengembangkan bakat dan penyaluran } \\
\text { minat/hobi }\end{array}$ & $25,26,27$ & 11 \\
\cline { 2 - 4 } & Tingkat hubungan dengan anggota keluarga & 17,19 & 1,10 \\
\cline { 2 - 4 } & Pola pergaulan di lingkungan sekolah & 24,28 & 9,16 \\
\cline { 2 - 4 } & $\begin{array}{l}\text { Keinginan beribadah dan melakukan kegiatan } \\
\text { keagamaan }\end{array}$ & 23 & 8 \\
\hline
\end{tabular}

Data penelitian yang sudah terkumpul selanjutnya akan dilakukan analisis data. Dalam penelitian ini, analisis data yang digunakan adalah analisis statistik inferensial Uji hipotesis statistik pada penelitian ini dianalisis dengan menggunakan Pearson product moment. Sebelum analisis dilakukan, data harus diuji terlebih dahulu dengan uji prasyarat analisis yaitu uji normalitas sebaran data. Uji normalitas dimaksudkan untuk memperlihatkan bahwa sebaran data sampel berdistribusi normal. Pengujian normalitas sebaran data pada penelitian ini menggunakan rumus Kolmogorov-Smirnov.

Adapun hipotesis penelitian yang akan diuji, yaitu: Tidak terdapat korelasi yang signifikan antara konsep diri dengan kemampuan pemecahan masalah siswa kelas V SD Gugus Untung Surapati Kecamatan Denpasar Timur Tahun Pelajaran 2017/2018.

\section{Hasil dan Pembahasan}

Berdasarkan hasil penelitian yang meliputi konsep diri dengan kemampuan pemecahan masalah IPS kelas V SD di Gugus Untung Surapati, Kecamatan Denpasar Timur, diperoleh data nilai maksimum pada variabel kemampuan pemecahan masalah IPS adalah 98 dan nilai minimum pada variabel kemampuan pemecahan masalah kompetensi inti pengetahuan IPS adalah 10. Berdasarkan tabel nilai PAP (Sumber : Agung, 2014) tentang kategori tingkat kemampuan pemecahan masalah IPS serta hasil dari analisis data dengan jumlah siswa 213 orang diperoleh $20 \%$ siswa dengan kemampuan pemecahan masalah IPS yang sangat kurang baik, 20\% siswa dengan kemampuan pemecahan masalah IPS yang kurang baik, $45 \%$ siswa dengan kemampuan pemecahan masalah IPS yang cukup baik, $12 \%$ siswa dengan kemampuan pemecahan masalah IPS yang baik, 2\% siswa dengan kemampuan pemecahan masalah IPS yang sangat baik. Sebaran data kemampuan pemecahan masalah IPS dapat ditunjukkan melalui grafik pada Gambar 2. 
TSCJ, Vol 2 No 1, Tahun 2019

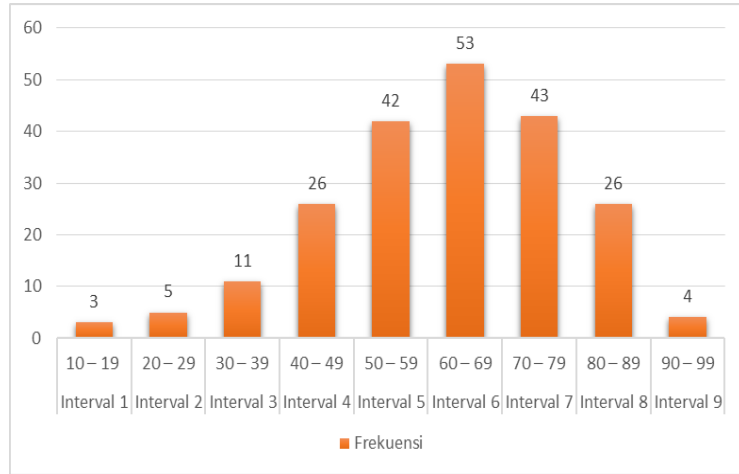

Gambar 2. Grafik Data Kemampuan Pemecahan Masalah IPS

Sedangkan berdasarkan hasil penelitian yang meliputi konsep diri dengan kemampuan pemecahan masalah IPS kelas V SD di Gugus Untung Surapati, Kecamatan Denpasar Timur, pada variabel konsep diri diperoleh nilai maksimum adalah 97 dan skor minimum pada konsep diri adalah 64, Berdasarkan tabel nilai PAP (Sumber: Agung, 2014) tentang kategori tingkat konsep diri serta hasil dari analisis data dengan jumlah siswa 213 orang diperoleh $1 \%$ siswa dengan konsep diri yang kurang baik, 33\% siswa dengan konsep diri yang cukup baik, $60 \%$ siswa dengan konsep diri yang baik, $6 \%$ siswa dengan konsep diri yang sangat baik. Sebaran data konsep diri dapat ditunjukkan melalui grafik pada gambar 3.

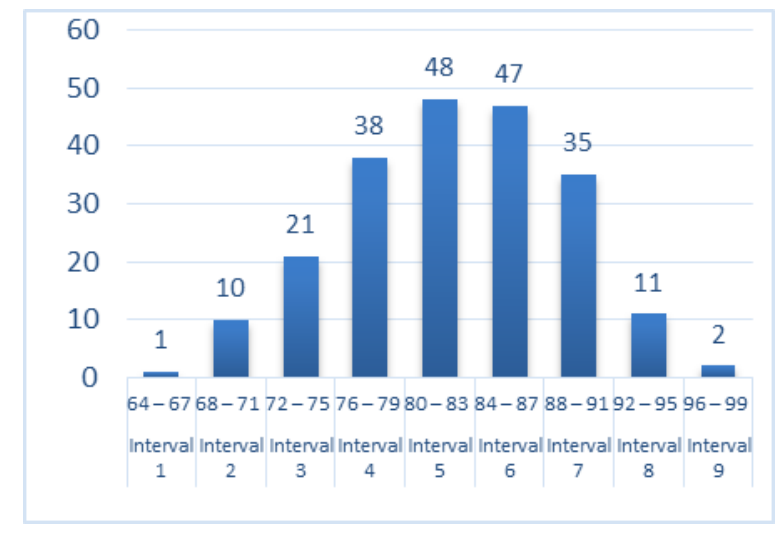

\section{Gambar 3. Grafik Data Konsep Diri}

Data yang diperoleh dari penelitian ini kemudian dianalisis menggunakan uji normalitas sebaran data Kolmogorov-Smirnov. Berdasarkan hasil analisis uji normalitas sebaran data pada taraf signifikansi $5 \%$ dan $\mathrm{dk}(1-\alpha ; n)$ diperoleh $\mathrm{KS}_{\text {tabel }}=0,093$. Hasil uji normalitas kemampuan pemecahan masalah IPS diperoleh $\mathrm{KS}_{\text {hitung }}=0,078$ kemudian nilai tersebut dibandingkan dengan $\mathrm{KS}_{\text {tabel }}=0,093$. Hal ini menunjukkan bahwa $\mathrm{KS}_{\text {hitung }}=0,078<\mathrm{KS}_{\text {tabel }}=0,093$, berarti data kemampuan pemecahan masalah IPS berdistribusi normal. Hasil uji normalitas konsep diri diperoleh $\mathrm{KS}_{\text {hitung }}=0,079$ kemudian nilai tersebut dibandingkan dengan $\mathrm{KS}_{\text {tabel }}=0,093$. Hal ini menunjukkan bahwa $\mathrm{KS}_{\text {hitung }}=0,079<\mathrm{KS}_{\text {tabel }}=0,093$, berarti data konsep diri berdistribusi normal.

Berdasarkan hasil analisis diperoleh antara konsep diri $(X)$ dengan kemampuan pemecahan masalah IPS (Y) siswa kelas V SD Gugus Untung Surapati Kecamatan Denpasar Timur Tahun Pelajaran 2017/2018 dengan nilai $r_{\text {hitung }}=0,446$ dan $r_{\text {tabel }}=0,138$ pada taraf signifikansi $5 \%$ dengan $\mathrm{dk}=213$, sehingga hasil analisis diperoleh $r_{\text {hitung }}=0,446>r_{\text {tabel }}=0,138$, maka Ha diterima yang artinya terdapat korelasi yang signifikan antara konsep diri dengan kemampuan pemecahan masalah IPS siswa kelas V SD Gugus Untung Surapati Kecamatan Denpasar Timur Tahun Pelajaran 2017/2018 diterima dan didapatkan bahwa konsep diri memiliki kontribusi yang cukup untuk membantu siswa dalam mengasah kemampuan pemecahan masalah IPS. Selebihnya dipengaruhi oleh faktor atau variabel lainnya.

Berdasarkan atas teori psikologi kognitif, kemampuan pemecahan masalah dapat membuat siswa belajar melalui upaya penyelesaian permasalahan dunia nyata secara 
terstruktur untuk mengonstruksi pengetahuan siswa. Pemecahan masalah dipandang sebagai suatu proses untuk menemukan kombinasi dari sejumlah aturan yang dapat diterapkan dalam upaya mengatasi situasi yang baru. Sejumlah aturan-aturan tersebut didapat dan telah dikuasai melalui kegiatan-kegiatan belajar sebelumnya. Belajar menurut Slameto (2010) dipengaruhi oleh, 1) faktor internal yang meliputi: faktor jasmaniah, faktor psikologis, dan faktor kelelahan, serta 2) faktor eksternal yang meliputi keluarga, sekolah dan masyarakat. Berdasarkan pemaparan Slameto, ada salah satu faktor internal yang mampu mempengaruhi kegiatan belajar siswa bahkan dapat mempengaruhi hasil belajar siswa yaitu konsep diri. Konsep diri adalah seluruh elemen yang membuat seseorang memiliki pandangan, kepercayaan dan keyakinan terhadap dirinya dan lingkungan.

Terdapat 2 jenis konsep diri, yaitu konsep diri positif dan konsep diri negatif. Menurut Taylor (2000) Siswa yang mempunyai konsep diri positif secara nyata mampu mengatasi masalah dalam kesehariannya, cenderung lebih independen, percaya diri, dan bebas dari karakteristik yang tidak diinginkan. Pada penelitian ini konsep diri cukup berkontribusi memberikan rasa kepercayaan diri siswa untuk menyelesaikan permasalahan yang ada. Selain itu, pada penelitian Ernawati (2015) menyatakan bahwa dengan konsep diri pada mempunyai dampak atau pengaruh terhadap pemecahan masalah pada siswa.

Dari teori serta hasil dari para peneliti tersebut telah mendukung terhadap hasil penelitian yang menyatakan terdapat korelasi yang signifikan antara berpikir kreatif dengan kemampuan pemecahan masalah IPS.

4.

\section{an dan Saran}

Simpul

Berdasarkan hasil analisis diperoleh $r_{\text {hitung }}=0,446$ dan $r_{\text {tabel }}=0,138$, karena $r_{\text {hitung }}=0,446$ $>r_{\text {tabel }}=0,138$, ini berarti $H_{0}$ ditolak dan $H_{a}$ diterima sehingga $H_{a}$ yang menyatakan terdapat korelasi yang signifikan antara konsep diri dengan kemampuan pemecahan masalah IPS siswa kelas V SD Gugus Untung Surapati Kecamatan Denpasar Timur tahun pelajaran 2017/2018 diterima. Kategori korelasi yang diperoleh termasuk korelasi yang cukup antara konsep diri dengan kemampuan pemecahan masalah IPS. Sedangkan arah korelasi adalah positif karena nilai $r$ positif, berarti semakin tinggi konsep diri siswa maka semakin meningkat pula kemampuan pemecahan masalah IPS.

Adapun saran yang dapat disampaikan berdasarkan hasil penelitian yang telah dilakukan yaitu: untuk orang tua agar dapat memberikan pendidikan, dukungan dan kasih sayang agar anak dapat mengembangkan konsep diri siswa ke arah yang positif. Melalui lingkungan keluarga khususnya orang tua yang baik dan pendidikan yang tepat maka anak akan dapat mengembangkan konsep diri dan kemampuan pemecahan masalahnya secara optimal. Untuk guru agar dapat memberikan dukungan, motivasi dan perhatian kepada siswa, karena peran serta guru di sekolah juga sangat menentukan pembentukan konsep diri pada siswa. Guru dapat menciptakan suasana pembelajaran yang kondusif, menyenangkan sehingga membuat siswa menjadi nyaman dan termotivasi untuk beradaptasi dengan lingkungan sekitarnya. Untuk kepala sekolah agar dapat menggunakan hasil penelitian ini sebagai referensi dalam mengambil kebijakan untuk mendukung pelaksanaan pembelajaran dalam meningkatkan kualitas pembelajaran, tidak hanya dari segi kognitif, tetapi juga dari segi afektif, khususnya dalam meningkatkan konsep diri positif pada siswa. Agar perkembangan afektif anak dapat terbentuk dengan baik melalui lingkungan sekolah yang tepat. Dan untuk peneliti lain agar hasil penelitian ini nantinya dapat digunakan sebagai referensi penelitian yang relevan untuk melaksanakan penelitian selanjutnya. Semoga penelitian ini bemanfaat bagi seluruh elemen masyarakat yang menggunakan penelitian ini.

\section{Daftar Pustaka}

Adiprabowo, Raihan. 2017. Positive Personalities.Yogyakarta: Brilliant Books.

Agung, A. A. Gede. 2014. Metodologi Penelitian Pendidikan Edisi 2. Singaraja: Aditya Media Publishing.

Bachri, Syamsul. 2013. Psikologi Pendidikan Berbasis Analisis Empiris Aplikatif. Jakarta: Kencana Prenada Media Group. 
TSCJ, Vol 2 No 1, Tahun 2019

p-ISSN : 2615-4692 e-ISSN : 2615-6105

Boeree, C. George. 2013. Personalities Theories: melacak Kepribadian Anda Bersama Psikolog Dunia. Jakarta: AR-RUZZ MEDIA.

BSNP. 2006. Standar Isi Untuk Satuan Pendidikan Dasar dan Menengah. Jakarta: Badan Standar Nasional Pendidikan.

Djaali. 2011. Psikologi Pendidikan. Jakarta: Bumi Aksara.

Emzir. 2012. Metode Penelitian Pendidikan. Jakarta: Rajawali Pers.

Ernawati, Renatha. 2015. "Pengaruh Konsep Diri Terhadap Pemecahan Masalah Bagi Siswa Kelas X Di SMA Negeri Jakarta Timur", Vol. 8, No. 3

Furchan, Arief. 2007. Pengantar Penelitian dalam Pendidikan. Yogyakarta: Pustaka Pelajar.

Jakni. 2016. Metodelogi Penelitian Eksperimen Bidang Penelitian. Bandung: Alfabeta.

Koyan, I Wayan. 2007. Asesmen dalam Pendidikan. Singaraja: Universitas Pendidikan Ganesha.

Latipah, Eva. 2012. Pengantar Psikologi Pendidikan. Yogyakarta: Pedagogia.

Mairing, Jackson Pasini. 2017. Statistika Pendidikan. Yogyakarta: CV. Andi Yogyakarta.

Mappiare A T, Andi. 2004. Pengantar Konseling dan Psikoterapi. Jakarta: Rajawali Pers.

Musriandi, Riki. 2017. "Hubungan Antara Self-Concept Dengan Kemampuan Pemecahan Masalah Sistematis Siswa". Vol. 1, No.2, (hlm 153-157)

Munirah. 2015. Sistem Pendidikan Di Indonesia: Antara Keinginan Dan Realita. Jurnal Auladuna, Vol. 2 No. 2 Desember 2015: 233-245

Nurkholis. 2013. Pendidikan Dalam Upaya Memajukan Teknologi . Jurnal Kependidikan, Vol. 1 No. 1 Nopember 2013

Pucangan, Ketut Yuning Jayasri. 2017. "Hubungan Antara Konsep Diri dan Pola Asuh Orang Tua Terhadap Hasil Belajar SD Kelas II", Vol. 5, No.2 (hlm 3)

Purnomo, Arif. 2016. Model Pembelajaran IImu Pengetahuan Sosial (Ips) Pada Materi Kontroversi (Controversy Issues) Di Sekolah Menengah Pertama (Smp) Kota Semarang. Jurnal Penelitian Pendidikan Vol. 33 Nomor 1 Tahun 2016

Sanjaya, I Wayan. "Korelasi Antara Berpikir Kreatif Dengan Kemampuan Pemecahan Masalah Kompetensi Inti Pengetahuan IPS Siswa Kelas V SDN 10 Sanur, Denpasar Selatan, Pada Tahun Pelajaran 2016/2017", Vol: , No.2 (hlm 7-8)

Santrock, John W. 2015. Psikologi Pendidikan. Jakarta: Kencana.

Setyosari, Punaji. 2015. Metode Penelitian Pendidikan dan Pengembangan. Jakarta: Kencana.

Siregar, Syofian. 2013. Metode Penelitian Kuantitatif. Jakarta: Kencana.

Slameto. 2010. Belajar dan Faktor-Faktor yang Mempengaruhinya. Jakarta: Rineka Cipta.

Sudijono, Anas. 2011. Pengantar Evaluasi Pendidikan. Jakarta: PT. Raja Grafindo Persada

Sukardi. 2016. Metodelogi Penelitian Pendidikan Kompetensi dan Praktiknya. Jakarta: Bumi Aksara. 
TSCJ, Vol 2 No 1, Tahun 2019

p-ISSN : 2615-4692 e-ISSN : 2615-6105

Sugiyono. 2012. Metode Penelitian Pendidikan Pendekatan Kuantitatif, Kualitatif, dan R\&D. Bandung: Alfabeta.

Sugiyono, 2017. Statistika Untuk Penelitian. Bandung: Alfabeta

Susanto, Ahmad. 2014. Teori Belajar dan Pembelajaran di Sekolah Dasar. Jakarta: Kencana Media Group.

Sutoyo, Anwar. 2012. Pemahaman Individu. Yogyakarta: Pustaka Pelajar.

Tri ,Yulia. 2017. Interaktif dalam Pembelajaran IPS . Jurnal IImiah PGMI Volume 3, Nomor 1, Juni 2017

Wena, Made. 2012. Strategi Pembelajaran Inovatif Kontemporer Suatu Tinjauan Konseptual Operasional. Jakarta: PT Bumi Aksara.

Winarsunu, Tulus. 2009. Statistik Dalam penelitian Psikologi \& Pendidikan. Malang: UMM Press 